\title{
Reflexões em diálogo
}

Caro leitor, é com alegria que lançamos a primeira edição da revista Literartes, uma publicação acadêmica, que visa a propiciar um espaço de reflexões sobre a arte literária. Uma web publicação que resulta das discussões e reflexões empreendidas pelo grupo de pesquisa Produções Literárias para Crianças e Jovens acerca da literatura produzida para crianças e jovens e dos diálogos que vem estabelecendo com outras linguagens, outras artes e suportes.

Ao rearticular-se à realidade mutante, essa literatura vem assumindo configurações renovadas nos diversos meios artísticos, os quais oferecem aos jovens leitores, espectadores ou internautas diferenciados modos de interação com o material literário, disponível no mercado. São livros, filmes, animações, games e outros que se disponibilizam, hoje, para a formação do processo leitor. Seguramente, cumpre aos educadores e estudiosos da literatura infantil e juvenil refinar o olhar para uma investigação do diálogo que a literatura estabelece com outras artes e com outras produções culturais na contemporaneidade, procurando evidenciar que novas configurações estéticas estão emergindo e, ademais, que relações estão estabelecendo nossas crianças e jovens com a leitura. Em última instância, importa desvelar mediações necessárias, na esfera educacional, para a formação de leitores literários. Isto implica atentar para componentes como a literariedade do texto, a qualidade estética da obra, a presença do lúdico, a recorrência aos gêneros do imaginário, a abordagem das temáticas e a linguagem com que essa forma de expressão propõe comunicação com seu destinatário.

Em suma, numa época em que a confluência de linguagens configura novas narrativas e os meios eletrônicos e a realidade virtual corporificam diferentes formas de interagir com as obras de arte, literárias ou não, uma reflexão sobre tais temas se torna necessária, sobretudo para compreendermos a formação dos jovens leitores e as ferramentas que dispomos para desenvolver um olhar crítico e criativo sobre o material literário.

Assim, a revista Literartes abre espaço para diferentes reflexões, proporcionando um diálogo profícuo sobre diversos temas relacionados à literatura e à literariedade. 


\title{
LITER2ARTES
}

O ciberespaço, a tecnologia do 3D, o mercado editorial do Brasil e de Portugal, a narrativa e a tradição nas lentes africanas, os mundos mágicos de Alice à Hugo Cabret, a tessitura da costura entre letras e ilustrações, enfim, esses e outros temas são abordados nessa edição, revelando um pouco do muito que resulta do diálogo interliterários. Até mesmo uma entrevista nos "tecidos do imaginário" com os irmãos Grimm poderá ser conferida nesse primeiro número da revista Literartes!

Esperamos que esse espaço possa contribuir para as reflexões sobre o diálogo entre literatura, arte e mídias, sobretudo no que diz respeito à produção para crianças e jovens e a formação dos leitores, possibilitando o contato entre diferentes formas de pensar e vivenciar tais reflexões. Boa leitura!

\author{
Maria Zilda da Cunha \\ Maria Cristina de Oliveira
}

